\title{
An Experiment on Biodigested Poultry Litter Slurry as a Source for Organic Cultivation of Vegetable Crop
}

\author{
V. Palaniselvam ${ }^{*}$, S. Pugalendhi ${ }^{2}$, S. Karthikeyan ${ }^{2}$ and N. Karthikeyan ${ }^{2}$ \\ ${ }^{1}$ Department. of Agronomy, Agriculture College and Research Institute, \\ TNAU, Killikulam, India \\ ${ }^{2}$ Department of Bioenergy, Agricultural Engineering College and Research Institute, \\ TNAU, Coimbatore, India \\ *Corresponding author
}

\section{A B S T R A C T}

\section{Keywords}

Biodigested slurry, Poultry droppings, Biogas, Anaerobic digestion

Article Info

Accepted: 10 October 2020 Available Online: 10 November 2020
The biogas technology is the only promising renewable energy source attributed with dual benefits in the form of supply of a clean and high calorific fuel to meet the domestic fuel needs of rural areas. It also emphasis with a provision of anaerobic treated bio digested slurry with high manure value. The poultry dropping and manure component of this waste has a high nutritional value and traditionally used as application on soil in open field as an organic manure. The present study was carried out to evaluate the effect of biodigested poultry litter slurry as a nitrogen source and compost generated by a biogas reactor. Field experiments were carried out with biodigested slurry supplemented with chemical fertilizer for the bhendi crop with five different treatments and replications with biodigested slurry direct application and biodigested slurry compost application. Among the treatments, application of $12.5 \mathrm{t} \mathrm{ha}^{-1}$ of biodigested compost showed maximum yield of $19.55 \mathrm{t} \mathrm{ha}^{-1}$ followed by the application of $9.37 \mathrm{t} \mathrm{ha}^{-1}$ of biodigested compost yield $18.78 \mathrm{t} \mathrm{ha}^{-1}$. Similarly results were obtained for the direct application of biodigested poultry slurry in the field with the maximum yield of $19.86 \mathrm{t} \mathrm{ha}^{-1}$ followed by $19.60 \mathrm{t} \mathrm{ha}^{-1}$ with the application rate of $75 \%$ slurry $+25 \% \mathrm{RDF}$ nitrogen and of $25 \%$ slurry $+75 \% \mathrm{RDF}$ nitrogen respectively. The study was concluded with the findings that supplementing the liquid slurry with fertilizer can save up to $75 \%$ of $\mathrm{N}$ fertilizer cost and $12.5 \mathrm{t} \mathrm{ha}^{-1}$ of biogas compost will improve the productivity of bhendi. The biodigested slurry from poultry droppings was found to be better alternative way of organic farming instead of direct application in rural areas. This may pave a way to utilize the local available resources to increase the income of the organic farming farmers.

\section{Introduction}

The biogas technology is the only promising renewable energy source attributed with dual benefits in the form of supply of a clean and high calorific fuel to meet the domestic fuel needs of rural areas. It also emphasis with a provision of anaerobic treated bio digested slurry with high manure value.

Injudicious and indiscriminate application of chemical fertilizers has created serious damages to the soil health, environment and its threatening the health of people, also now 
a day the cost of chemical fertilizers is going up very high. The farmers are getting used to organic manures to reduce the expenses towards fertilizers.

Organic farming has been considered to be a sound and viable option in most of the countries. However the decline in livestock population has lead to non availability of farm yard manure.

\section{Materials and Methods}

The present study for evaluating the effect of biodigested poultry litter slurry (slurry from anaerobic digestion process utilizing $1 \%$ poultry litter, $1 \%$ press mud and $0.05 \%$ cow dung) as a nitrogen source and compost (solid portion of the slurry) generated by a biogas reactor, applied as basal in separate field for the production of bhendi (Abelmoschus esculentus, $L$ ).

The nitrogen: phosphorus:potash content of the biodigested poultry slurry and biodigested compost was 1.85:0.73:1.12 \% and 1.64:0.86:1.02\% respectively. To enhance the nitrogen and phosphorus content of the compost it was enriched with azophos biofertilizer.

Field experiments was carried out with biodigested poultry slurry supplemented with chemical fertilizer for the behendi crop and treatment as (T5: $0 \%$ slurry $\mathrm{N} \mathrm{ha}^{-1}$ ) with four other different levels of treatments. The treatment were $\mathrm{T}_{1}\left(25 \%\right.$ of slurry $\left.\mathrm{N} \mathrm{ha}^{-1}\right), \mathrm{T}_{2}$ $\left(50 \%\right.$ of slurry $\left.\mathrm{N} \mathrm{ha}^{-1}\right), \mathrm{T}_{3}(75 \%$ of slurry $\mathrm{N}$ $\left.\mathrm{ha}^{-1}\right)$ and $\mathrm{T}_{4}\left(100 \%\right.$ of slurry $\mathrm{N}$ ha $\left.^{-1}\right)$ replicated field trail with randomized block design.

Another experiment were conducted with compost application the treatments were as $T_{1}$ (12.5 $\mathrm{t} \mathrm{ha}^{-1}$ farm yard manure), $\mathrm{T}_{2}\left(3.1 \mathrm{t} \mathrm{ha}^{-1}\right.$ compost), $\mathrm{T}_{3}$ (6.5 $\mathrm{t} \mathrm{ha}^{-1}$ farm yard manure), $\mathrm{T}_{4}$ (9.37 $\mathrm{t} \mathrm{ha}^{-1}$ compost) and $\mathrm{T}_{5}\left(12.5 \mathrm{t} \mathrm{ha}^{-1}\right.$ compost) with recommended dose of fertilizer (RDF).

\section{Results and Discussion}

The results from the field experiments with different treatments of slurry applied in the field and yield were given in table 1 .

Among the five treatments with biodigested slurry applied field the higher yield was recorded as $19.86 \mathrm{t} \mathrm{ha}^{-1}$ in the treatment by $\mathrm{T}_{3}$ (75\% of slurry $+25 \%$ RDF Nitrogen) followed by $\mathrm{T}_{1}(25 \%$ of slurry $+75 \% \mathrm{RDF}$ Nitrogen) as $19.60 \mathrm{t} \mathrm{ha}^{-1}$ when compared to other treatment $\mathrm{T}_{5}-100 \% \mathrm{RDF}$ alone which was recorded the yield of $19.67 \mathrm{tha}^{-1}$. Similar work was conducted with biodigested slurry alongside NPK fertilizers applied at reduced rates significantly increased the okra yield by $25-36 \%$ (Shahbaz et al.,)

Table.1 Effect of poultry litter biodigested slurry on bhendi yield

\begin{tabular}{|l|l|c|}
\hline S.No & $\begin{array}{l}\text { Slurry applied in the field with } \\
\text { treatments }\left(\mathbf{N ~ h a}^{-\mathbf{1}}\right)\end{array}$ & $\begin{array}{c}\text { Yield of Bhendi } \\
\text { (tones } / \text { ha) }\end{array}$ \\
\hline 1. & $\mathrm{T}_{1}-(25 \%$ of slurry $+75 \% \mathrm{RDF})$ & 19.60 \\
\hline 2. & $\mathrm{T}_{2}-(50 \%$ of slurry $+50 \% \mathrm{RDF})$ & 18.98 \\
\hline 3. & $\mathrm{T}_{3}(75 \%$ of slurry $+25 \% \mathrm{RDF})$ & 19.86 \\
\hline 4. & $\mathrm{T}_{4}(100 \%$ of slurry+ $\%$ RDF $)$ & 16.17 \\
\hline 5. & $\mathrm{T} 5: 100 \%$ RDF alone & 19.67 \\
\hline
\end{tabular}


Table.2 Effect of application of poultry litter compost on bhendi yield

\begin{tabular}{|l|l|c|}
\hline S.No & Poultry litter compost applied in the field with treatments & Yield of Bhendi (tonnes/ha) \\
\hline 1. & $\mathrm{T}_{1}-12.5 \mathrm{tha}^{-1}$ Farm yard manure & 19.35 \\
\hline 2. & $\mathrm{T}_{2}-3.1 \mathrm{tha}^{-1}$ compost & 16.43 \\
\hline 3. & $\mathrm{T}_{3}-6.5 \mathrm{tha}^{-1}$ compost & 16.63 \\
\hline 4. & $\mathrm{T}_{4}-9.37 \mathrm{tha}^{-1}$ compost & 18.78 \\
\hline 5. & $\mathrm{T}_{5}-12.5 \mathrm{tha}^{-1}$ compost & 19.55 \\
\hline
\end{tabular}

The results on the application of poultry litter compost treatment and yield of bhendi crop was given in table 2 .

The poultry litter compost applied in the field at the rate of $12.5 \mathrm{t} \mathrm{ha}^{-1}$ compost in the treatment $\mathrm{T}_{5}$ showed the higher yield of 19.55 $\mathrm{t} \mathrm{ha}^{-1}$ followed by the treatment $\mathrm{T}_{4}$ with the application rate of $9.37 \mathrm{t} \mathrm{ha}^{-1}$ compost yields $18.78 \mathrm{t} \mathrm{ha}^{-1}$ when compared to treatment $\mathrm{T}_{1}$ with $12.5 \mathrm{t} \mathrm{ha}^{-1}$ Farm yard manure with the yield recorded as $19.35 \mathrm{t} \mathrm{ha}^{-1}$.

In conclusion the experiment on effect of biodigested poultry litter slurry as a nitrogen sources for organic cultivation of bhendi crop with different treatment of poultry litter biodigested slurry and compost was carried out in the field.

From the study, it was concluded that supplementary addition of slurry with the fertilizer can save $75 \%$ of the $\mathrm{N}$ fertilizer cost and $12.5 \mathrm{t} \mathrm{ha}^{-1}$ of poultry litter biodigested compost will improve the productivity of bhendi crop. The experiments on poultry litter slurry was carried out with the financial support from the TNAU-IOT collaborative project on poultry litter based biomethanation plant slurry handling and enrichment scheme.

\section{References}

Stuart T. Nakamoto Ping Sun Leung Kulavit Wanitprapha (1994) The value of diluted poultry slurry Bioresource Technology 48 (1): $25-30$

Ghimire, A (2002). A review on organic farming for sustainable agriculture, Project report, Institute of Agriculture and Animal science, Nepal.

Indira, V and Dhasarthan, P (2011) Biopesticde impact on growth of Abelmaschus exculantus Linn. Seedlings, Intl. Journal on Pharma Bioscience., 2(1):124-136.

Shahbaz, M, Akhtar, M.J., Ahmad, W and Wakeel, A. (2014). Integrated effect of different N-Fertilizer rates and bioslurry application on growth and N-use efficiency of okra (Abeimaschus exculantus Linn). Turk. J.Agric. For, 38:311-319.

Eruin M Ribeiro, Regina Mambeli Barros, Geraldo Lúcio Tiago Filho, Ivan Felipe $\mathrm{S}$ dos Santos, Luma C Sampaio, Ticiane V dos Santos, Fernando dGB da Silva, Ana Paula M Silva, João Victor R de Freitas (2018). Feasibility of biogas and energy generation from poultry manure in Brazil aste management and Research 36 (3): 221-235.

\section{How to cite this article:}

Palaniselvam, V., S. Pugalendhi, S. Karthikeyan and Karthikeyan, N. 2020. An Experiment on Biodigested Poultry Litter Slurry as a Source for Organic Cultivation of Vegetable Crop. Int.J.Curr.Microbiol.App.Sci. 9(11): 1187-1189. doi: https://doi.org/10.20546/ijcmas.2020.911.138 